\title{
A Human T Cell Clone That Mediates the Monocyte Procoagulant Response to Specific Sensitizing Antigen
}

\author{
Bradford S. Schwartz, Pamela J. Reitnauer, Jacquelyn A. Hank, and Paul M. Sondel \\ Departments of Medicine, Human Oncology, Genetics, and Pediatrics, University of Wisconsin, Madison, Wisconsin 53706
}

\begin{abstract}
A panel of human purified protein derivative of the tubercle bacillus (PPD)-reactive $T$ cell clones was derived by cloning out of soft agar followed by cultivation on inactivated feeder cells in the presence of interleukin-2. 1 of 4 clones tested was able to mediate an increase in monocyte procoagulant activity (PCA) in response to $P P D$. All four clones had identical surface marker phenotypes $\left(\mathrm{T}_{4^{+}}, \mathrm{T}_{8^{-}}\right)$and proliferated in response to antigen. The reactive $T$ cell clone possessed no PCA of its own, but upon being presented with PPD was able to instruct monocytes to increase their expression of PCA. Antigen presentation could be performed only by autologous monocytes; allogeneic monocytes from donors unrelated to the donor of the reactive clone could not present antigen to cells of the clone in a way that would initiate the procoagulant response. Cells of the reactive clone did not mediate increased monocyte PCA in response to Candida, even though peripheral blood mononuclear cells from the donor demonstrated increased PCA to both Candida and PPD. Thus, the PCA response to specific antigen can be mediated by a single clone of cells that shows specificity in the recognition of both antigen and antigen presenting cell.
\end{abstract}

\section{Introduction}

Human peripheral blood monocytes have been shown to increase surface expression of a procoagulant activity (PCA) ${ }^{1}$ upon stimulation with a variety of agents (1). Most described stimuli, such as bacterial lipopolysaccharide (LPS), are polyclonal activators. No specific recognition of the stimulus by a distinct reactive cellular subset is required for the reaction to take place. Cells of the immune system can also respond to a specific sensitizing protein antigen by increasing surface expression of PCA $(2,3)$.

This report was presented in abstract form at the annual meeting of the American Heart Association, 1984, in Miami, FL.

Dr. Sondel is a Scholar of the Leukemia Society of America. Both Drs. Schwartz and Sondel are fellows of the John A. Hartford Foundation. Address correspondence to Dr. Schwartz. 1985

Received for publication 29 April 1985 and in revised form 10 June

1. Abbreviations used in this paper: FCS, fetal calf serum; LPS, lipopolysaccharide; PBM, peripheral blood mononuclear cells; PCA, procoagulant activity; PPD, purified protein derivative of the tubercle bacillus; $\left[{ }^{3} \mathrm{H}\right] \mathrm{TdR}$, tritiated thymidine.

J. Clin. Invest.

(c) The American Society for Clinical Investigation, Inc.

0021-9738/85/09/1279/04 \$1.00

Volume 76, September 1985, 1279-1282
This reactivity demonstrates specificity, as protein antigen to which an individual is not sensitized will not cause that individual's peripheral blood mononuclear cells (PBM) to express increased amounts of PCA $(2,4)$. The cellular interactions required for expression of PCA in response to polyclonal activators, and a specific sensitizing antigen, or alloantigen, appear to be quite different (4-7). The LPS-driven response requires the stimulus to interact with $T$ cells, which then instruct monocytes to synthesize and express increased amounts of PCA. The response reaches maximum amplitude in as short as $6 \mathrm{~h} \mathrm{(5).} \mathrm{The}$ response to specific, complex antigen, however, requires that the antigen first be processed by the monocyte/macrophage (8). As might be predicted from analyses of other immune functions, the antigen-presenting cell presents antigen to immune lymphocytes which can then instruct a second population of monocytes to express high levels of PCA (4). These interactions require between 24 and $48 \mathrm{~h}$ to develop maximum amounts of PCA, and the interactions can be blocked by a monoclonal antibody that binds the HLA-DR antigen (4). These findings are highly suggestive of a role for monocyte PCA in the controlled, specific immune response. To further investigate this and allow studies of interactions between well-defined cell populations, we examined a series of purified protein derivative of tubercle bacillus (PPD)-reactive human T cell clones for their ability to cooperate with monocytes in the production of monocyte PCA.

\section{Methods}

Cell and incubations. Antigens were PPD (National Institute of Allergy and Infectious Diseases, Bethesda, MD) and Candida Albicans yeast phase disrupted at 10,000 psi. A panel of PPD-specific T cell clones derived from peripheral blood lymphocytes of an individual who demonstrated a positive skin test to this antigen were prepared by soft agar cloning as previously described $(9,10)$. These cells were selected for specific proliferative responses to PPD, maintained on irradiated autologous feeder PBM, and grown in the presence of T cell growth factor $(9$, 10). Clones were maintained in vitro for up to 3 mo before use in these experiments. Commercially available monoclonal antibody reagents to human lymphocyte surface markers and fluorescence-activated flow cytometry (11) (Ortho model 50 flow cytometer, Ortho Pharmaceutical Corp., Raritan, NJ) demonstrated that all four $\mathrm{T}$ cell clones used in these experiments had uniform characteristics: all demonstrated $>98 \%$ of cells positive for OKT3, OKT11, and OKT4; and $<1 \%$ of cells positive for OKT8 (Ortho Pharmaceutical Corp.), B1 (Coulter Electronics, Hialeah, FL), and Leu-MI (Becton-Dickinson \& Co., Mountain View, CA). PBM were prepared by Ficoll-Hypaque centrifugation or fresh heparinized human peripheral venous blood $(5,6)$. T cell clones or PBM were tested for proliferation in response to specific antigen by uptake of $\left[{ }^{3} \mathrm{H}\right]$ thymidine $\left(\left[{ }^{3} \mathrm{H}\right] \mathrm{TdR}\right)(9,10)$. Briefly, PBM $\left(2 \times 10^{5}\right)$, T cell clones $\left(1 \times 10^{5}\right)$, inactivated $(2,500 \mathrm{rad})$ PBM feeder cells $\left(1 \times 10^{5}\right)$, or indicated combinations were incubated in $0.25-\mathrm{ml}$ roundbottom microtiter wells (Linbro, 
Flow Laboratories, McLean, VA) in RPMI-1640 (Gibco Laboratories, Grand Island, NY), supplemented with $25 \mathrm{mM}$ Hepes (Gibco Laboratories), $2 \mathrm{mM}$ L-glutamine (Gibco Laboratories), $50 \mathrm{U} / \mathrm{ml}$ penicillin, 50 $\mu \mathrm{g} / \mathrm{ml}$ streptomycin, and $15 \%$ heat inactivated $\left(56^{\circ} \mathrm{C}, 30 \mathrm{~min}\right)$ pooled human serum. PCA was determined in a parallel set of cultures no sooner than $10 \mathrm{~d}$ after the addition of irradiated feeder cells, at which time no feeder cells remained. Cells of individual $\mathrm{T}$ cell clones were combined with autologous monocytes that had been isolated by incubating 5 $\times 10^{6} \mathrm{PBM} / \mathrm{ml}$ RPMI-1640 plus $10 \%$ human serum in $35-\mathrm{mm}$ gelatincoated plates (12). The cells were incubated for $2 \mathrm{~h}$ at $37^{\circ} \mathrm{C}, 5 \% \mathrm{CO}_{2}$, nonadherent cells washed off, and monocytes were removed by incubating at $4^{\circ} \mathrm{C}$ in Puck's Saline A (Gibco Laboratories) without $\mathrm{Ca}^{++}$, supplemented with $25 \mathrm{mM}$ Hepes buffer and $1 \mathrm{mM}$ EDTA. After further washing in RPMI-1640, the monocytes (95-98\% nonspecific esterase positive [13]) were used as indicated. For elaboration of PCA, PBM $\left(1 \times 10^{6}\right)$, cloned $\mathrm{T}$ cells $\left(5 \times 10^{5}\right)$, monocytes $\left(1 \times 10^{5}\right)$, or indicated combinations were incubated $48 \mathrm{~h}$ at $37^{\circ} \mathrm{C}, 5 \% \mathrm{CO}_{2}$ in $1 \mathrm{ml} \mathrm{RPMI}-1640$ supplemented as above with the exclusion of human serum; $10 \%$ heat inactivated fetal calf serum (FCS) (Sterile Systems, Logan, UT) was used instead. The cells were then washed with, and resuspended in $0.5 \mathrm{ml}$ serum-free RPMI1640 for PCA assay. Viability of monocytes was always $>89 \%$ at time of assay.

$P C A$ assay $(5,6)$. Cell suspension $(0.1 \mathrm{ml})$ and pooled human, plateletpoor plasma (anticoagulated with final concentration of $0.38 \%$ sodium citrate) $(0.1 \mathrm{ml})$ were combined at $37^{\circ} \mathrm{C} . \mathrm{CaCl}_{2}(0.1 \mathrm{ml}$ of $25 \mathrm{mM})$ was added and time-to-clot formation measured by fibrometer. Clotting time in seconds was transformed to milliunits PCA by reference to a standard curve. Undiluted rabbit brain thromboplastin (American Dade, Miami, FL) reconstituted as per manufacturer's recommendations was assigned an activity of $100,000 \mathrm{mU}$. Tenfold dilutions of this thromboplastin were assayed for clotting time to generate a standard curve for coagulant activity that was linear from 1 to $10,000 \mathrm{mU}$. Clotting assays on dilutions of PCA-positive monocytes generated a curve parallel to that obtained with rabbit brain thromboplastin. PCA is expressed as milliunits (a linear parameter) for ease of comparison between values. Values given are mean \pm SD of 2-4 experiments, each done in duplicate.

\section{Results}

It can be seen from Table I that unfractionated PBM from the individual from which the $\mathrm{T}$ cell clones were derived showed a tenfold increase in PCA when exposed to PPD as compared with cells that were exposed to medium alone. Similarly, antigenexposed PBM showed a 20-fold increase in $\left[{ }^{3} \mathrm{H}\right] \mathrm{TdR}$ uptake as compared with medium-exposed controls. Each $\mathrm{T}$ cell clone derived from this individual showed impressive proliferation in response to soluble PPD. Cultures measuring proliferation were carried out in the presence of irradiated autologous PBM to serve as antigen-presenting cells. $T$ cell clones cultured with antigen alone in the absence of antigen-presenting cells showed no $\left[{ }^{3} \mathrm{H}\right] \mathrm{TdR}$ uptake (data reported previously, reference 9 ).

In parallel cultures, only cells from clone T.15, cultured in the presence of autologous monocytes, were able to induce an increase in monocyte PCA upon exposure to antigen as compared with control cultures (Table I). The PCA was tissue factorlike in that it required Factors VII and X, but not Factor VIII, to exert coagulant activity (data not shown). Three other clones, all of which were able to proliferate in response to PPD, did not induce significant amounts of monocyte PCA (Table I). Monocytes alone, with no added lymphocytes, showed a slight increase in PCA upon the addition of antigen. In all probability, this was due to the few (2-5\% by nonspecific esterase staining) lymphocytes that remained in the adherent cell population. Cells from the $\mathrm{T}$ cell clones alone consistently demonstrated no detectable PCA. PBM that were irradiated and kept in culture for $1 \mathrm{wk}$, as were the irradiated feeder cells, likewise showed no ability to increase monocyte PCA upon addition of antigen.

We next sought to demonstrate antigen specificity of the procoagulant response as has been shown for whole peripheral blood mononuclear cells (2-4). The individual from whom the

Table I. A Human PPD-Reactive T Cell Clone Which Mediates the Monocyte Procoagulant Response and Proliferates Upon Exposure to Sensitizing Antigen

\begin{tabular}{|c|c|c|c|c|}
\hline \multirow[b]{2}{*}{ Cell population* } & \multicolumn{2}{|c|}{ mU PCA $/ 10^{5}$ monocytes } & \multicolumn{2}{|c|}{ cpm[ $\left.{ }^{3} \mathrm{H}\right] \mathrm{TdR}$ uptake§ } \\
\hline & Control" & PPDT & Control" $^{\prime \prime}$ & PPDI \\
\hline Peripheral blood mononuclear cells & $7 \pm 1$ & $75 \pm 7$ & $1,565 \pm 698$ & $31,521 \pm 2,478$ \\
\hline T.15 + Monocytes ${ }^{* *}$ & $7 \pm 5$ & $74 \pm 10$ & $977 \pm 134$ & $18,736 \pm 2,739$ \\
\hline T.8 + Monocytes** & $<3$ & $7 \pm 5$ & $661 \pm 574$ & $9,088 \pm 765$ \\
\hline T.11 + Monocytes** & $<3$ & $17 \pm 14$ & $504 \pm 383$ & $39,821 \pm 1,808$ \\
\hline T.50 + Monocytes** & $<3$ & $7 \pm 2$ & $48 \pm 5$ & $59,737 \pm 3,600$ \\
\hline Monocytes $* *$ & $7 \pm 3$ & $14 \pm 7$ & ND" & ND \\
\hline T.15, T.8, T.11, or T.50ł alone & $<3$ & $<3$ & ND & ND \\
\hline Irradiated PBM§§ and monocytes** & $6 \pm 2$ & $7 \pm 0$ & ND & ND \\
\hline Irradiated PBM§§ & $<3$ & $<3$ & ND & ND \\
\hline No cells" "I & $<3$ & $<3$ & ND & ND \\
\hline
\end{tabular}

\footnotetext{
* Indicated cell populations incubated in the presence or absence of PPD and assayed for PCA or proliferation as described in Methods. $¥$ PBM, cloned T cells, monocytes $\left(1 \times 10^{3}\right)$, or indicated combinations were incubated with or without PPD, then assayed for PCA as in Methods. § PBM, T cell clones, inactivated PBM feeder cells, or indicated combinations were incubated $6 \mathrm{~d}$ for PBM and $3 \mathrm{~d}$ for $\mathrm{T}$ cell clones. $\left[{ }^{3} \mathrm{H}\right] \mathrm{TdR}(1$ $\mu \mathrm{Ci}$ ) was assayed as in Methods. Values are mean $\mathrm{cpm} \pm \mathrm{SD}$ of quadruplicate samples from a representative experiment performed in parallel with the same cell populations tested in the PCA assay. "Supplemented RPMI without antigen in volume identical to PPD was added to parallel cultures. I $10 \mu \mathrm{g} / \mathrm{ml}$ PPD in supplemented RPMI-1640. ** Human monocytes (95-98\% nonspecific esterase positive) from same donor as T cell clones, were prepared as in Methods. $¥ \mathrm{~T}$ cells of the indicated clones which had been grown $7 \mathrm{~d}$ with inactivated feeder cells (PBM irradiated 2,500 rad) were washed twice, cultured as indicated, and assayed for PCA. \$\$ Irradiated PBM used as feeder cells for T cell clones (same donor) incubated in the presence and absence of PPD, and assayed for PCA as above. "I Medium alone, with no cells, incubated with or without PPD, and assayed for PCA as above. IT Not done.
} 
$\mathrm{T}$ cell clones had been derived was also known to be sensitive to Candida. His peripheral blood mononuclear cells responded to a disrupted Candida antigen preparation (9) as assessed by both $\left[{ }^{3} \mathrm{H}\right] \mathrm{TdR}$ uptake and monocyte PCA (Table II). However, clone T.15 combined with autologous monocytes induced no increase in monocyte PCA in response to Candida antigen. Parallel cultures again showed a vigorous procoagulant response to the sensitizing antigen, PPD. Likewise, the reactivity of clone T.15 as assessed by proliferation showed specificity for PPD with only the slightest response to Candida antigen.

Specific antigen induction of monocyte PCA requires antigen presentation by monocytes to lymphocytes (4). This step is absent in the response to the polyclonal stimulators LPS or immune complexes $(5,6)$. Cells from clone T.15 incubated with PPD, then washed free of unbound antigen, were unable to induce an increase in PCA among monocytes to which they were added (Table III). However, if autologous monocytes were first incubated with soluble PPD, then washed free of unbound protein and combined with cells of clone T.15, the cells of clone T.15 were subsequently able to induce increased PCA in a second population of autologous monocytes to which they were added. Cells of T.15 that were combined with antigen-pulsed monocytes from another donor were unable to induce increases in PCA among a population of autologous monocytes to which they were subsequently added. It was important in these experiments that the responding monocytes be completely devoid of lymphocytes. Otherwise, some of the antigen-presenting monocytes from the first step of the experiment would be detached from the plate and transferred with the T.15 cells to the responding monocytes. If the responding monocytes had some alloreactive $T$ cells in their midst, one would be hard pressed to differentiate alloantigen-induced monocyte PCA (14) from the antigen-in-

Table II. Clone T.15 Mediates Procoagulant Production Only in Response to Sensitizing Antigen

\begin{tabular}{|c|c|c|c|}
\hline Cell population* & Antigen & $\begin{array}{l}\text { mU PCA } / 10^{5} \\
\text { monocytesł }\end{array}$ & $\begin{array}{l}\text { cpm }\left[{ }^{3} \mathrm{H}\right] \mathrm{TdR} \\
\text { uptake§ }\end{array}$ \\
\hline $\mathrm{A}^{\| 1} \mathrm{PBM}$ & - & $7 \pm 2$ & $1,292 \pm 612$ \\
\hline $\mathrm{A}^{\|} \mathrm{PBM}$ & CandidaI & $115 \pm 10$ & $43,310 \pm 14,286$ \\
\hline$A^{\prime \prime}$ PBM & PPD ${ }^{* *}$ & $75 \pm 5$ & $23,121 \pm 5,154$ \\
\hline$A^{\text {ll Monocytes + T.15 }}$ & - & $5 \pm 1$ & $1,200 \pm 323$ \\
\hline A" Monocytes + T.15 & Candida & $5 \pm 0$ & $5,247 \pm 1,688$ \\
\hline 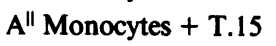 & PPD & $95 \pm 20$ & $47,018 \pm 4,175$ \\
\hline A $^{\text {ll Monocytes }}$ & - & $5 \pm 2$ & NDł‡ \\
\hline All Monocytes $^{\prime \prime}$ & Candida & $7 \pm 4$ & ND \\
\hline All Monocytes $^{\prime \prime}$ & PPD & $5 \pm 2$ & ND \\
\hline $\mathrm{T} .15$ & - & $<3$ & $674 \pm 906$ \\
\hline T.15 & Candida & $<3$ & $867 \pm 525$ \\
\hline T.15 & PPD & $<3$ & $1,782 \pm 732$ \\
\hline
\end{tabular}

* Cell populations, culture conditions, and assay procedures were as outlined in Methods.

$¥$ Mean \pm SD two experiments done in duplicate.

$\S$ Mean \pm SD representative experiment done in triplicate.

"Individual from whom T.15 was derived, with skin test positive to PPD and Candida.

I Candida Albicans yeast phase disrupted at 10,000 psi, 1:50 dilution of stock.

** $10 \mu \mathrm{g} / \mathrm{ml}$ PPD.

拉 Not done.
Table III. Clone T.15 Requires Antigen

Presentation by Autologous Monocytes

\begin{tabular}{|c|c|c|c|c|}
\hline \multirow{2}{*}{$\begin{array}{l}\text { Cell populations added } \\
\text { to responding } \\
\text { monocytes* }\end{array}$} & \multicolumn{2}{|c|}{$\begin{array}{l}\text { mU PCA/10s } \\
\text { monocytes } \ddagger\end{array}$} & \multicolumn{2}{|c|}{ cpm $\left[{ }^{3} \mathrm{H}\right] \mathrm{TdR}$ uptake§ } \\
\hline & Control" & PPDI & Control" & PPDI \\
\hline No cells & $<3$ & $4 \pm 1$ & ND & ND \\
\hline T.15 & $5 \pm 2$ & $14 \pm 2$ & $133 \pm 124$ & $267 \pm 58$ \\
\hline T.15 + A monocytes $* *$ & $7 \pm 5$ & $81 \pm 11$ & $189 \pm 137$ & $45,531 \pm 952$ \\
\hline T.15 + B monocytesłł & $6 \pm 1$ & $5 \pm 2$ & $444 \pm 84$ & $1,196 \pm 345$ \\
\hline A monocytes** & $7 \pm 4$ & $16 \pm 3$ & ND & ND \\
\hline B monocytesł‡ & $6 \pm 1$ & $7 \pm 3$ & ND & ND \\
\hline
\end{tabular}

* Indicated cell populations prepared as in Methods. T.15 at $5 \times 10^{5} / \mathrm{ml}$, monocytes at $1 \times 10^{5} / \mathrm{ml}$.

¥ Wells of 24-well polystyrene plates containing monocyte suspensions from donors A or B (see below), or medium alone, were "pulsed" with PPD or medium, and incubated for $4 \mathrm{~h}$ at $37^{\circ} \mathrm{C}, 5 \% \mathrm{CO}_{2}$. The cells or plates were washed two times with the same medium, and either T.15 cells or no cells were added in 1 ml RPMI-10\% FCS for a further 14-h incubation. The nonadherent cells (<5\% nonspecific esterase positive) were recovered, washed twice, and added to one times $10^{5}$ monocytes ( $299 \%$ nonspecific esterase positive) from donor $A$ for an additional $24 \mathrm{~h}$. The responding monocytes were then assayed for PCA as in Table I. Results are mean \pm SD of four experiments using three different "donor B" monocytes.

$\S$ Indicated cell population incubated $72 \mathrm{~h}$ in 96 -well roundbottom plates at $37^{\circ} \mathrm{C}, 5 \% \mathrm{CO}_{2}$ in RPMI-1640,L 15\% human serum. The "monocyte" population for the proliferation experiment represents irradiated (2,500 rad) PBM from the indicated donor. Since this part of the experiment was a measure of proliferation of the T.15 clone in the context of antigen presentation, no "responding monocyte" population was needed.

"RPMI-1640 + 10\% human serum.

I $10 \mu \mathrm{g} / \mathrm{ml}$ PPD.

* Monocytes from same donor as clone T.15.

$\$$ Monocytes from donor other than, and unrelated to, the source of clone T.15.

duced PCA mediated by clone T.15. With monocyte populations $>99 \%$ nonspecific esterase positive, we were able to show a specific PDD-induced effect that was dependent upon antigen presentation by autologous monocytes. This indicates that the triggering of clone T.15 by PPD to a procoagulant inductive state requires the simultaneous recognition of surface antigens on autologous monocytes. Presumably these antigens are one part of the HLA system, since helper and cytotoxic $T$ cell responses to PPD involve simultaneous recognition of HLA determinants (15-17).

\section{Discussion}

Clonality for the clones used here was never documented by subcloning (18). However, two lines of evidence suggest that the cells of T.15 as well as the other T cell clones were each derived from a single $T$ cell. First, individual colonies were plucked from soft agar cultures and thereafter expanded in the generation of these clones. The clones were maintained in $\mathrm{T}$ cell growth factor, a process that activates and expands many cell types, including those bearing the OKT8 marker, those bearing the T4 marker, and some cells that lack mature $T$ cell markers $(19,20)$. However, use of commercially available monoclonal antibody reagents to human lymphocyte surface markers and fluorescence-activated flow cytometry (11), demonstrated that all four $\mathrm{T}$ cell clones used in these experiments had uniform characteristics: all were $>98 \%$ positive for OKT3, OKT11, and OKT4, and $<1 \%$ positive 
for OKT8, OKB1, or Leu-M1. Had these initial colonies been derived from a mixed population of cells, one would expect cellular heterogeneity with some cells expressing the OKT8 marker, as well as some cells without any mature $\mathrm{T}$ cell markers. The data are therefore consistent with clonality.

Only clone T.15, but not clones T.8, T.11, or T.50, mediated the monocyte procoagulant response to PPD, in spite of identical surface marker phenotypes and uniform patterns of proliferative responses to PPD presented by autologous monocytes. It is possible that clones T.8, T.11, or T.50 at one time had the capability of inducing monocyte PCA in response to specific antigen, but lost this function with in vitro cultivation. It seems possible, however, that only a distinct subset of $\mathrm{T}$ cells that are able to proliferate in response to a given antigen may mediate the development of monocyte PCA in response to that antigen. There may be distinct helper cell subtypes that respond to the same antigen, yet mediate separate helper cell interactions with different "effector" cells (i.e., cytotoxic T cells, NK cells, B cells, and monocytes). Responding monocytes required contact with cells of clone T.15 to develop PCA. We were unable to demonstrate a soluble product of clone T.15 that could induce monocyte PCA (data not shown). Perhaps other $\mathrm{T}$ cell clones that were not screened are able to secrete such factors into the medium. Aside from PCA and proliferation, other helper cell functions were not tested for in these clones.

The demonstration that monocyte PCA can be induced by a single $\mathrm{T}$ cell-derived clone in response to the specific sensitizing antigen speaks for a role of monocyte PCA in the immune response. These cellular reagents will make it possible to accurately describe the cellular events and interactions that are necessary in this particular effector mechanism of the immune response.

\section{Acknowledgments}

We are indebted to Peggy Barden, Diana Hanson, and Cindy Paulson for superb secretarial assistance.

We gratefully acknowledge the support of this work by National Institutes of Health grants AI-20247 (to Dr. Schwartz) and CA-32685 (to Dr. Sondel).

\section{References}

1. Edwards, R. L., and F. R. Rickles. 1980. The role of monocyte tissue factor in the immune response. In Lymphokine Reports, Vol. 1. E. Pick, editor. Academic Press, Inc., New York. 181-240.

2. Geczy, G. L., and P. A. Meyer. 1982. Leukocyte procoagulant activity in man: an in vitro correlate of delayed type hypersensitivity. $J$. Immunol. 128:331-336.

3. Edwards, R. L., and F. R. Rickles. 1978. Delayed hypersensitivity in man: effects of systemic anticoagulation. Science (Wash. DC). 200: 541-543.

4. Schwartz, B. S. 1985. Antigen-induced monocyte procoagulant activity: requirement for antigen presentation and histocompatibility leukocyte antigen-DR molecules. J. Clin. Invest. 76:970-977.

5. Levy, G. A., B. S. Schwartz, and T. S. Edgington. 1981. The kinetics and metabolic requirements for direct lymphocyte induction of human procoagulant monokines by bacterial lipopolysaccharide. J. Immunol. 127:357-363.

6. Schwartz, B. S., and T. S. Edgington. 1981. Immune complex induced human monocyte procoagulant activity. I. A rapid unidirectional lymphocyte instructed pathway. J. Exp. Med. 154:894-905.

7. Helin, H., and T. S. Edgington. 1984. A distinct "slow" cellular pathway involving soluble mediators for the T-cell instructed induction of monocyte tissue factor activity in an allogeneic immune response. $J$. Immunol. 132:2457-2463.

8. Unanue, E. R. 1984. Antigen presenting function of the macrophage. In Annual Review of Immunology, Vol. 2. W. E. Paul, editor. Annual Reviews, Inc., Palo Alto, CA. 395-428.

9. Reitnauer, P. J., L. R. Brown, J. A. Hank, and P. M. Sondel. 1983. Proliferative responses to a nonspecific factor produced by irradiated stimulating cells can simulate antigen specific secondary responses in the primed lymphocyte test. J. Immunol. 131:165-171.

10. Fathman, C. A., and J. G. Frelinger. 1983. T lymphocyte clones. In Annual Review of Immunology, Vol. 1. W. E. Paul, editor. Annual Reviews, Inc., Palo Alto, CA. 633-656.

11. Reinholz, E. L., and S. F. Schlossman. 1980. The differentiation and function of human T-lymphocytes. Cell. 19:821-829.

12. Leb, L., T. Crusberg, N. Fortier, and L. M. Snyder. 1983. Evaluation of methods using adherence to substrate and density gradients for the isolation of human monocytes. J. Immunol. Methods. 58:309318.

13. Yam, L. T., C. Y. Li, and W. H. Crosby. 1971. Cytochemical identification of monocytes and granulocytes. Am. J. Clin. Pathol. 55: 238-246.

14. Helin, H., and T. S. Edgington. 1983. Allogeneic induction of the human T-cell instructed monocyte response is rapid and is elicited by HLA-DR. J. Exp. Med. 158:962-975.

15. Berghultz, B. O., and E. Thorsby. 1978. HLA-D restriction of the macrophage dependent response of human immune $T$ lymphocytes to PPD in vitro: inhibition by anti-HLA-DR antisera. Scand. J. Immunol. 8:63-73.

16. Hank, J. A., and P. M. Sondel. 1982. Soluble bacterial antigen induces specific helper and cytotoxic responses by human lymphocytes in vitro. J. Immunol. 128:2734-2739.

17. Hansen, P. W., M. Madsen, G. E. Christiansen, H. E. Johnsen, and F. Kissmeyer-Nielsen. 1984. Cell mediated PPD specific cytotoxicity against human monocyte targets. Tissue Antigens. 23:171-176.

18. Bach, F. 1983. On getting a T-cell clone and being assured you have one. Immunol. Today. 4:243-245.

19. Rosenberg, S. A., E. A. Grimm, M. T. Lotze, and A. Muzumder. 1982. The growth of human lymphocytes in T-cell growth factor. potential applications to tumor immunotherapy. In Lymphokines. E. Pick, editor. Academic Press, Inc., New York. 7:213-235.

20. Raubitschek, A., J. D. Lifson, C. Renike, K. Koths, A. Amman, P. M. Sondel, and E. Engleman. 1984. Purified interleukin-2 induces in vitro proliferation of fresh human luekocytes in absence of exogenous stimuli. Submitted for publication. 